\title{
Cultivar, harvest year, and storage conditions affecting nutritional quality of common beans (Phaseolus vulgaris L.)
}

\author{
Cultivar, ano de cultivo e condições de armazenagem influenciam \\ a qualidade nutricional do feijão-comum (Phaseolus vulgaris L.)
}

\author{
Ivo Roberto Dorneles PROLLA ${ }^{1,2}$, Roberta Garcia BARBOSA ${ }^{1}$, Ana Paula Lima VEECK ${ }^{1}$, \\ Paula Rossini AUGUSTI ${ }^{1}$, Leila Picolli da SILVA ${ }^{3}$, Nerinéia Dalfollo RIBEIRO ${ }^{4}$, Tatiana EMANUELLI ${ }^{1 *}$
}

\begin{abstract}
Sixteen common bean cultivars were compared concerning the physicochemical characteristics of their raw seeds in the course of two consecutive harvests, as well as the effect of storage conditions on starch and dietary fiber content of cooked beans. Using cluster analysis it was possible to identify groups of cultivars with different nutritional features. Bean cultivars were categorized into four different groups according either to their macronutrient content (crude protein-PROT, total dietary fiber-TDF, insoluble dietary fiber-IDF, soluble dietary fiber-SDF, digestible starch-DS, and resistant starch-RS) or to their micronutrient levels (Fe, $\mathrm{Zn}, \mathrm{Mn}, \mathrm{Cu}, \mathrm{Ca}, \mathrm{Mg}$, and P). Guateian 6662 and Rio Tibagi appeared to be the most suitable cultivars to prevent nutritional deficiencies, because they had high PROT, DS, Fe, and Zn content. The high total dietary fiber and RS content of Iraí, Minuano, and TPS Bonito cultivars, and specially the high soluble fiber content of Guateian 6662 and Rio Tibagi cultivars suggests that they could have a beneficial role in controlling blood lipid and glucose levels. Cooked beans had a decrease in DS and an increase in RS content after storage $\left(4^{\circ} \mathrm{C}\right.$ or $\left.-20^{\circ} \mathrm{C}\right)$, but these changes were more prominent in beans that had low RS content before cooking than in those of high RS content. TDF, IDF, and SDF did not change after storage.

Keywords: dietary fiber; digestible starch; resistant starch; mineral content.
\end{abstract}

\section{Resumo}

Compararam-se as características físico-químicas de dezesseis cultivares de feijão-comum cru ao longo de duas safras consecutivas, assim como se avaliou o efeito das condições de armazenagem nos teores de amido e fibra alimentar em grãos cozidos. A análise de agrupamento possibilitou a identificação de grupos de cultivares com características nutricionais distintas. Estas cultivares foram categorizadas em quatro grupos de acordo com o conteúdo de macronutrientes (proteína bruta-PROT, fibra alimentar total-TDF, fibra alimentar insolúvel-IDF, fibra alimentar solúvel-SDF, amido disponível-DS e amido resistente-RS) ou de micronutrientes (Fe, Zn, Mn, Cu, Ca, Mg, e P). Guateian 6662 e Rio Tibagi mostraram-se as cultivares mais adequadas para prevenir deficiências nutricionais, devido aos altos teores de PROT, DS, Fe e Zn. Os altos teores de fibra alimentar total e RS das cultivares Iraí, Minuano e TPS Bonito, e especialmente os altos teores de fibra solúvel das cultivares Guateian 6662 e Rio Tibagi sugerem que estas poderiam auxiliar no controle dos lipídios e glicose séricos. Os grãos cozidos apresentaram redução no DS e aumento de RS após armazenagem $\left(4{ }^{\circ} \mathrm{C}\right.$ ou $\left.-20{ }^{\circ} \mathrm{C}\right)$, mas estas alterações foram mais pronunciadas em feijões que tinham baixos teores de RS antes do cozimento do que naqueles com altos teores. Os teores de TDF, IDF, e SDF não alteraram após a armazenagem.

Palavras-chave: fibra alimentar; amido disponível; amido resistente; conteúdo mineral.

\section{Introduction}

Common beans (Phaseolus vulgaris L.) are grown and consumed throughout the world. They play an important role in the nutrition of low-income people especially in developing countries, where they are often the most important dietary source of protein, carbohydrate, dietary fiber, and minerals (THARANATHAN; MAHADEVAMMA, 2003). It is noteworthy that protein energy undernutrition and micronutrient deficiencies in childhood can be prevented if beans and cereals are appropriately combined. Besides the nutritional role, bean consumption has other potential benefits for human health such as lowering the risk of colon cancer and of heart disease, reducing total and LDL cholesterol, and regulating blood glucose and insulin levels (THE MICHIGAN BEAN COMMISSION, 2008).

Different chemical characteristics can be found in beans according to the genetic variety (BARAMPAMA; SIMARD, 1993; KIGEL, 1999). Genetic research concerning bean culture is mainly aimed at improving productivity and resistance to field pests and environmental stress. Although, there is evidence

\footnotetext{
Recebido para publicação em 19/4/2008

Aceito para publicação em 3/1/2009 (003327)

${ }^{1}$ Núcleo Integrado de Desenvolvimento em Análises Laboratoriais (NIDAL), Departamento de Tecnologia e Ciência dos Alimentos, Centro de Ciências Rurais,

Universidade Federal de Santa Maria - UFSM, Camobi, CEP 97105-900, Santa Maria - RS, Brasil, Email: tatiemanuelli@smail.ufsm.br

${ }^{2}$ Departamento de Pediatria e Puericultura, Centro de Ciências da Saúde, Universidade Federal de Santa Maria - UFSM, Camobi, CEP 97105-900, Santa Maria - RS, Brasil

3 Departamento de Zootecnia, Centro de Ciências Rurais, Universidade Federal de Santa Maria - UFSM, Camobi, CEP 97105-900, Santa Maria - RS, Brasil

${ }^{4}$ Departamento de Fitotecnia, Centro de Ciencias Rurais, Universidade Federal de Santa Maria - UFSM, Camobi, CEP 97105-900, Santa Maria - RS, Brasil

${ }^{*}$ A quem a correspondência deve ser enviada
} 
that it may also change physicochemical characteristics of seeds and affect their nutritional value, studies concerning these changes in beans are still rare and limited to few cultivars (AUGUSTIN et al., 1981; BARAMPAMA; SIMARD, 1993; NUNEZ-GONZALEZ et al., 2002).

Nutrient profile of beans may also be affected by environmental factors (SAMMAN et al., 1999), which could make it difficult to obtain standard nutritional values for seeds cultivated in different regions and from different harvests. However, some studies in cereal cultivars (oat, rice, and wheat) indicate that despite the changes in absolute values due to environmental factors, cultivars may keep a standard compositional pattern, i.e. higher or lower starch or protein content (STORCK; SILVA; FAGUNDES, 2005).

Besides these changes in chemical characteristics due to genetic and environmental factors, certain processing techniques, such as cooking and storage conditions, can also produce important changes in starch, fiber, and other components of legume seeds (KUTOS et al., 2003; VARGAS-TORRES et al., 2004). These changes may affect the digestibility and nutritional value of foods containing common bean seeds. All this variability has remarkable importance for strict diets that are based on food composition tables, which usually do not show specific values for different bean cultivars, nor their possible changes in the course of harvest years. In addition, bean seeds of better nutritional quality could be supplied for low-income populations around the world.

Carbohydrates are the major component of beans. Current knowledge on nutritional features of starch indicates that a fraction of this carbohydrate is resistant to enzyme digestion in the small intestine. This resistant starch can be a substrate for the fermentation process in the colon with important benefits for human health, similar to the dietary fiber. However, relatively few studies evaluated resistant starch and dietary fiber content of common beans (KUTOS et al., 2003; VARGAS-TORRES et al., 2004; LANDA-HABANA et al., 2004), while most studies evaluated total starch content and crude fiber content that do not give a real picture of the nutritional implications of these components (ANTUNES et al., 1995; CASTELLÓN et al., 2003; LEMOS et al., 2004).

The objectives of the present study were: (a) to compare the physicochemical characteristics of sixteen common bean cultivars recommended for planting in southern Brazil; (b) to investigate the persistence of the nutrient profile in the course of two harvests; and (c) to assess the effect of storage conditions on digestible starch, resistant starch, and dietary fiber contents of cooked beans. Results will be useful for local dietitians to choose the most appropriate cultivars for specific nutritional purposes such as public health programs (health policy) and strict dietary orientations.

\section{Materials and methods}

\subsection{Samples}

Common bean seeds (Phaseolus vulgaris L.) of sixteen cultivars (Carioca, Diamante Negro, FTS Magnífico, FTS
Soberano, Guapo Brilhante, Guateian 6662, IAPAR 31, Iraí, Macanudo, Minuano, Pérola, Rio Tibagi, TPS Bionobre, TPS Bonito, TPS Nobre, and Valente) that are recommended for planting in southern Brazil were obtained from the Department of Fitotecnia of the Federal University of Santa Maria, Rio Grande do Sul, Brazil. They were grown during two consecutive years (2001/2002 and 2002/2003) at the campus, which is located at an altitude of $95 \mathrm{~m}$. The local climate, according to Köppen's classification, is Cfa - subtropical, with total average annual rainfalls and temperature around $1769 \mathrm{~mm}$ and $19.2{ }^{\circ} \mathrm{C}$, respectively. The soil is a typical dystrophic red (BANDINELLI et al., 2005). In both harvest years, seeds were grown under similar field conditions and normal agronomic practices required for bean crops were followed. Each cultivar was obtained from three independent lots of land, each one containing four rows $(4 \mathrm{~m}$ length and $50 \mathrm{~cm}$ row to row distance). After harvest, seeds from the three lots were pooled and a representative sample (200 g) of each cultivar was taken and kept at $-20{ }^{\circ} \mathrm{C}$ in sealed polyethylene bags until analysis. As all the physical and chemical analyses were performed at the same time, seeds from the first harvest were kept frozen for approximately twelve months longer than seeds from the second harvest.

\subsection{Physical analysis}

One thousand seed mass ( $\mathrm{g}$ ) was calculated as ten times the mass of 100 seeds. The evaluation was performed in unbroken raw seeds chosen at random.

\subsection{Chemical analysis}

\section{Raw bean analysis}

Raw seeds (50 g) were finely ground into flour and kept at $-20{ }^{\circ} \mathrm{C}$ in sealed polyethylene bags until analysis. Bean flours were analyzed as described by AOAC (1995) for moisture (method 925.10), ash (method 923.03), fat (method 945.39), crude protein (method 960.52, $\mathrm{N} \times 6.25$, microKjeldahl method), and crude fiber (method 962.09). Dry matter and organic matter were calculated as 100 minus the centesimal content of moisture and ash, respectively. Digestible and resistant starch were determined after enzymatic hydrolysis according to the method no. 996.11 AOAC (1995, reviewed in 1998) as modified by Walter (2005) that uses a higher amount of sample (300 mg instead of $100 \mathrm{mg}$ ), phosphate buffer $\mathrm{pH} 6.8$ instead of MOPS (4-morpholinepropanesulfonic acid) buffer $\mathrm{pH} 7.0$, and proteolysis during digestion process. Amylose value was determined by iodometric assay (blue value; GILBERT; SPRAGG, 1964). Total and insoluble dietary fiber contents were determined by enzymic-gravimetric methods no. 985.29 and no. 991.42 (AOAC, 1995) and soluble dietary fiber content was calculated by difference. The enzymes employed for dietary fiber and starch determination were: $a$-amylase (Termamyl $120 \mathrm{~L}^{\oplus}$ ), protease (Flavourzyme ${ }^{\circledast}$ ), and amyloglucosidase (AMG 300L ${ }^{\circledR}$ ) supplied by Novozymes Latin American Ltda. (Araucária, PR, Brazil). Activity and purity of the enzymes was controlled weekly in our laboratory. For starch determination, glucose was measured using glucose-oxidase-peroxidase test kit 
(Glucox 500) supplied by Doles (Goiânia, GO, Brazil). Calcium, iron, zinc, copper, manganese, and magnesium were determined by atomic absorption spectroscopy, and phosphorus content was determined colorimetrically (TEDESCO et al., 1995).

All experiments were conducted at least in duplicate. Duplicates falling within $10 \%$ of their mean were accepted to be showing satisfactory agreement. The analysis was repeated if the agreement was outside $10 \%$ of the mean for the duplicates, and then recalculated on the basis of all concordant replicates. Reagent blanks were always run with samples and helped to monitor the purity of the reagents used. Any significant value for the blank determination was accounted for in the calculation of the results. Analytical quality control was monitored through the use of in-house control and participation in the inter-laboratory proficiency testing scheme (INTERLAB) of the Science and Technology Foundation (CIENTEC, Porto Alegre, RS, Brazil) that follows ISO and IUPAC guidelines for inter-laboratory proficiency testing.

\section{Cooked bean analysis}

Based on raw seed analysis, four cultivars of high resistant starch content (FTS Magnífico, IAPAR 31, Pérola, and TPS Bonito) and four cultivars of low resistant starch content (Diamante Negro, Iraí, Macanudo, and Valente) were chosen in order to determine the effect of storage conditions on starch and dietary fiber contents of cooked beans. Fifty grams of bean seeds were soaked overnight in tap distilled water $(250 \mathrm{~mL})$ at room temperature. Twelve hours later, they were cooked with the soaking water in beakers covered by an aluminum foil until they became suitable for consumption (approximately 40 minutes). Cooking was conducted in the laboratory at $95 \mathrm{~m}$ above sea level at the boiling water temperature (about $99.6{ }^{\circ} \mathrm{C}$ ). The cooked seeds were either immediately analyzed (control) or stored with the cooking water in sealed containers at $4{ }^{\circ} \mathrm{C}$ for 4 days or at $-20^{\circ} \mathrm{C}$ for 28 days. At the moment of the analysis, the seeds were drained off, dried on a paper towel, and ground into a paste.

Total, insoluble, and soluble dietary fiber, as well as the digestible and resistant starch contents were determined in cooked beans according to the same methods described above. Dry matter was determined after 48 hours at $55^{\circ} \mathrm{C}$ in an assisted air circulation oven, followed by 8 hours at $105^{\circ} \mathrm{C}$. All experiments were conducted at least in duplicate.

\section{Statistical analysis}

For evaluation of year to year variability, data concerning physicochemical characteristics from the two consecutive harvests were compared using the Student's $t$-test for paired samples $(\mathrm{P}<0.05)$ considering each cultivar sample as an independent replicate $(n=16)$. The correlations between the various physicochemical characteristics evaluated were assessed by Pearson's correlation in the whole population of cultivars studied $(n=16)$ separately in each harvest year.

Bean cultivars were divided into groups with distinctive chemical characteristics by cluster analysis using Ward's method as indicated by Hair Jr. et al. (1998). This technique is a classification procedure that groups objects in clusters in terms of their nearness or similarity for a set of variables. The measurement of the similarity is based, among other things, on the squared Euclidean distance. Data were standardized ( $\mathrm{Z}$ score) before cluster analysis in order to eliminate the bias introduced by the disparities in the scales of the different variables (chemical characteristics) used in the analysis. Since small differences were observed in the physicochemical characteristics if the course of the two harvests evaluated, results from the two harvests were used as two independent replicates of each cultivar in the cluster analysis. Comparisons among groups obtained by cluster analysis were made separately for each chemical characteristic by one-way analysis of variance (ANOVA) using untransformed values. Post-hoc analysis was carried out using Duncan's test $(\mathrm{P}<0.05)$.

The effect of storage conditions on the levels of digestible starch, resistant starch, total dietary fiber, insoluble dietary fiber, and soluble dietary fiber of cooked beans were evaluated using two-way ANOVA ( 2 types of sample $\times 3$ storage conditions, with 4 independent replicates per group). Post-hoc analysis was carried out using Duncan's test $(\mathrm{P}<0.05)$. The software used for all analysis was SPSS (1997).

\section{Results and discussion}

\subsection{Influence of harvest year on physicochemical characteristics of bean cultivars}

Seed characteristics are determined by cultivar genotype and environmental conditions during plant growth and seed development. Table 1 shows the average physicochemical characteristics of the sixteen bean cultivars in the course of two consecutive harvests (2001/2002 and 2002/2003). The average values were similar to those reported for other common bean cultivars (BARAMPAMA; SIMARD, 1993; ANTUNES et al., 1995; UNIVERSIDADE DE SÃO PAULO, 2008; UNIVERSIDADE ESTADUAL DE CAMPINAS, 2008). Most physicochemical characteristics evaluated did not change significantly throughout the harvests, except for the slight moisture decrease $(\mathrm{P}<0.05)$ and total dietary fiber increase $(\mathrm{P}<0.05$; Table 1) from the first to the second harvest. These changes may be related to the length of storage before assays that was longer (about 12 months) for seeds of the first harvest when compared to the second harvest. On average, these results indicate that the various cultivars exhibited a constant profile for most nutrients in the course of the two harvests.

Although no major differences were observed in the average chemical characteristics of seeds between the two harvests, remarkable ranges were observed in physical (1000 seeds mass) and chemical characteristics (ash, crude protein, crude fiber, dietary fiber, crude fat, amylose, and starch content) within each harvest (Table 1). Common beans are important dietary sources of protein, starch, and fiber. Therefore, the range in the content of protein (36\%), insoluble dietary fiber (70\%), soluble dietary fiber (106\%), digestible starch (77\%), and resistant starch (100\%) could be used to categorize bean cultivars according to their nutritional potential. 
We assessed the correlations between the various physicochemical characteristics shown in Table 1. Similar to the results of Lemos et al. (2004) we also found a significant negative correlation between protein (PROT) and 1000 seed mass ( $r=-0.65$ for harvest 1 and -0.55 for harvest 2$)$, indicating that bigger seeds have lower PROT content.

Table 1. Physicochemical characteristics of common bean seeds from 2 consecutive harvests (2001/2002 and 2002/2003).

\begin{tabular}{|c|c|c|}
\hline \multirow[t]{2}{*}{ Characteristics } & \multicolumn{2}{|c|}{ Harvest year } \\
\hline & $(2001 / 2002)$ & $(2002 / 2003)$ \\
\hline 1000 seed mass $(\mathrm{g})$ & $\begin{array}{c}223.19 \pm 9.74 \\
(165.00-331.70)\end{array}$ & $\begin{array}{c}230.59 \pm 10.48 \\
(158.40-338.60)\end{array}$ \\
\hline $\begin{array}{l}\text { Dry matter } \\
\text { (g.100 g }{ }^{-1} \text { dry weight) }\end{array}$ & $\begin{array}{c}86.67 \pm 0.13 \\
(85.92-87.57)\end{array}$ & $\begin{array}{c}87.09 \pm 0.12^{\star} \\
(86.09-87.79)\end{array}$ \\
\hline $\begin{array}{l}\text { Organic matter } \\
\text { (g.100 g-1 dry weight) }\end{array}$ & $\begin{array}{c}96.12 \pm 0.12 \\
(95.50-97.07)\end{array}$ & $\begin{array}{r}96.16 \pm 0.14 \\
(95.46-97.33)\end{array}$ \\
\hline $\begin{array}{l}\text { Moisture } \\
\text { (g.100 g }{ }^{-1} \text { dry weight) }\end{array}$ & $\begin{array}{c}13.33 \pm 0.13 \\
(12.43-14.08)\end{array}$ & $\begin{array}{c}12.91 \pm 0.12^{*} \\
(12.21-13.91)\end{array}$ \\
\hline $\begin{array}{l}\text { Ash } \\
\text { (g.100 g-1 dry weight) }\end{array}$ & $\begin{array}{l}3.90 \pm 0.12 \\
(2.93-4.50)\end{array}$ & $\begin{array}{l}3.84 \pm 0.14 \\
(2.67-4.54)\end{array}$ \\
\hline $\begin{array}{l}\text { Crude protein } \\
\text { (g.100 g }{ }^{-1} \text { dry weight) }\end{array}$ & $\begin{array}{c}25.69 \pm 0.55 \\
(21.24-29.06)\end{array}$ & $\begin{array}{c}25.11 \pm 0.41 \\
(22.50-27.96)\end{array}$ \\
\hline $\begin{array}{l}\text { Crude fiber } \\
\text { (g.100 g-1 dry weight) }\end{array}$ & $\begin{array}{l}4.79 \pm 0.17 \\
(3.64-5.72)\end{array}$ & $\begin{array}{l}4.98 \pm 0.18 \\
(3.54-6.05)\end{array}$ \\
\hline $\begin{array}{l}\text { Total dietary fiber } \\
\text { (g.100 g-1 dry weight) }\end{array}$ & $\begin{array}{r}23.97 \pm 0.54 \\
(20.79-28.79)\end{array}$ & $\begin{array}{l}25.35 \pm 0.72^{\star} \\
(21.02-31.91)\end{array}$ \\
\hline $\begin{array}{l}\text { Insoluble dietary fiber } \\
\text { (g.100 } \mathrm{g}^{-1} \text { dry weight) }\end{array}$ & $\begin{array}{r}18.81 \pm 0.65 \\
(13.80-23.49)\end{array}$ & $\begin{array}{r}19.50 \pm 0.50 \\
(16.97-22.79)\end{array}$ \\
\hline $\begin{array}{l}\text { Soluble dietary fiber } \\
\text { (g.100 g } \mathrm{g}^{-1} \text { dry weight) }\end{array}$ & $\begin{array}{r}5.17 \pm 0.48 \\
(3.59-10.68)\end{array}$ & $\begin{array}{l}5.90 \pm 0.60 \\
(1.44-9.72)\end{array}$ \\
\hline $\begin{array}{l}\text { Crude fat } \\
\text { (g.100 g }{ }^{-1} \text { dry weight) }\end{array}$ & $\begin{array}{l}1.90 \pm 0.25 \\
(0.98-5.49)\end{array}$ & $\begin{array}{l}1.82 \pm 0.21 \\
(0.92-4.43)\end{array}$ \\
\hline $\begin{array}{l}\text { Amylose } \\
\text { (g.100 g }{ }^{-1} \text { dry weight) }\end{array}$ & $\begin{array}{r}8.35 \pm 0.28 \\
(6.16-10.08)\end{array}$ & $\begin{array}{c}9.02 \pm 0.21 \\
(7.54-10.34)\end{array}$ \\
\hline $\begin{array}{l}\text { Digestible starch } \\
\text { (g.100 g }{ }^{-1} \text { dry weight) }\end{array}$ & $\begin{array}{r}29.40 \pm 1.15 \\
(20.02-35.61)\end{array}$ & $\begin{array}{c}30.81 \pm 1.12 \\
(23.66-39.41)\end{array}$ \\
\hline $\begin{array}{l}\text { Resistant starch } \\
\text { (g.100 g-1 dry weight) }\end{array}$ & $\begin{array}{l}3.34 \pm 0.18 \\
(2.35-4.70)\end{array}$ & $\begin{array}{c}3.44 \pm 0.17 \\
(2.46-4.58)\end{array}$ \\
\hline
\end{tabular}

\subsection{Categorizing bean cultivars according to their macronutrient content}

Previous studies discuss separately the variation of each nutrient among bean cultivars (AUGUSTIN et al., 1981; BARAMPAMA; SIMARD, 1993; KIGEL, 1999). However, this approach provides an incomplete analysis of the nutritional potential of different cultivars. Therefore, in the present study we used the multivariate cluster analysis to classify the set of cultivars into groups of different nutritional quality based on their similarities for a set of characteristics. Table 2 shows characteristics of groups formed by multivariate cluster analysis based on their similarity for the content of some macronutrients measured along two consecutive harvests (crude protein-PROT, total dietary fiber-TDF, insoluble dietary fiber-IDF, soluble dietary fiber-SDF, digestible starch-DS, and resistant starch-RS). These nutrients were chosen, based on the relevance of common beans intake as a dietary source. According to cluster analysis cultivars were divided into four groups (Table 2). Group A that was formed by cultivars TPS Bonito, Iraí, and Minuano had low PROT, high TDF, IDF, DS, and RS, and intermediate levels of SDF. Group B (Carioca, FTS Magnífico, FTS Soberano, Guapo Brilhante, IAPAR 31, Pérola, TPS Bionobre, and TPS Nobre) had intermediate levels of PROT and IDF, low levels of TDF and SDF, but high levels of DS and RS. Group C (Diamante Negro, Macanudo, and Valente) also had intermediate PROT and IDF levels, and low TDF and SDF, but in contrast to group B, group C had low levels of DS and RS. Group D (Guateian 6662 and Rio Tibagi) had the highest PROT and SDF levels, high DS levels, low TDF and IDF, and intermediate RS levels.

It is known that different biological effects can occur depending on the levels of nutrients in the diet. The present data shows that the genetic variability among bean cultivars significantly influenced its chemical characteristics. Among these cultivars, those that exhibited an interesting nutritional profile could be selected for specific dietary purposes, for example, cultivars from group D (high PROT and DS levels) could be used for undernutrition prevention. Some macronutrients like TDF, IDF, SDF and RS have been demonstrated to reduce serum lipid levels, and regulate blood insulin and glucose levels (GUILLON; CHAMP, 2002; HIGGINS, 2004). Hence, cultivars from groups A (high TDF and IDF, intermediate SDF, and high

Table 2. Groups formed by bean cultivars considering the levels of macronutrients. ${ }^{*}$

\begin{tabular}{|c|c|c|c|c|c|c|}
\hline \multirow[t]{2}{*}{ Group/cultivars } & \multicolumn{6}{|c|}{ Macronutrients (g. $100 \mathrm{~g}^{-1}$ dry weight) } \\
\hline & PROT & TDF & IDF & SDF & DS & RS \\
\hline A: Iraí; Minuano; TPS Bonito & $\begin{array}{l}22.93^{c} \downarrow \\
(0.67)\end{array}$ & $\begin{array}{l}28.83^{\mathrm{a} \uparrow} \\
(0.18)\end{array}$ & $\begin{array}{l}22.31^{\mathrm{a} \uparrow} \\
(0.22)\end{array}$ & $\begin{array}{l}6.51^{\mathrm{a}, \mathrm{b}} \uparrow \\
(0.36)\end{array}$ & $\begin{array}{l}31.73^{\mathrm{a}} \uparrow \\
(0.85)\end{array}$ & $\begin{array}{l}3.81^{\mathrm{a} \uparrow} \\
(0.40)\end{array}$ \\
\hline $\begin{array}{l}\text { B: Carioca; FTS Magnífico; FTS Soberano; Guapo } \\
\text { Brilhante; Iapar 31; Pérola; TPS Bionobre; TPS Nobre }\end{array}$ & $\begin{array}{l}25.61^{\mathrm{b} \uparrow} \\
(0.41)\end{array}$ & $\begin{array}{l}23.96^{\mathrm{b}} \downarrow \\
(0.38)\end{array}$ & $\begin{array}{l}19.23^{\mathrm{b}} \uparrow \\
(0.46)\end{array}$ & $\begin{array}{l}4.72^{\mathrm{b}} \downarrow \\
(0.44)\end{array}$ & $\begin{array}{l}31.54^{\mathrm{a}} \uparrow \\
(1.40)\end{array}$ & $\begin{array}{l}3.60^{\mathrm{a}} \uparrow \\
(0.19)\end{array}$ \\
\hline C: Diamante Negro; Macanudo; Valente & $\begin{array}{l}25.59^{\mathrm{b}} \uparrow \\
(0.85)\end{array}$ & $\begin{array}{r}22.7^{b} \downarrow \\
(0.50)\end{array}$ & $\begin{array}{l}17.84^{\mathrm{b}, c} \uparrow \\
(0.57)\end{array}$ & $\begin{array}{l}4.87^{\mathrm{b}} \downarrow \\
(0.57)\end{array}$ & $\begin{array}{l}24.29^{\mathrm{b}} \downarrow \\
(1.68)\end{array}$ & $\begin{array}{l}2.50^{\mathrm{b}} \downarrow \\
(0.02)\end{array}$ \\
\hline D: Guateian 6662; Rio Tibagi & $\begin{array}{l}27.96^{\mathrm{a}} \uparrow \\
(0.26)\end{array}$ & $\begin{array}{l}24.15^{\mathrm{b}} \downarrow \\
(0.28)\end{array}$ & $\begin{array}{l}16.04^{\mathrm{c}} \downarrow \\
(0.64)\end{array}$ & $\begin{array}{l}8.11^{\mathrm{a}} \uparrow \\
(0.92)\end{array}$ & $\begin{array}{l}30.60^{\mathrm{a}} \uparrow \\
(3.02)\end{array}$ & $\begin{array}{l}3.24^{\mathrm{a}, \mathrm{b}} \uparrow \\
(0.30)\end{array}$ \\
\hline
\end{tabular}

${ }^{*}$ Results are mean (standard error) of the group of cultivars indicated in the first column, each one analyzed in two harvests (2001/2002 and 2002/2003). Values within the same column that have no common superscript are significantly different $(\mathrm{P}<0.05$, Duncan's test). PROT: crude protein; TDF: total dietary fiber; IDF: insoluble dietary fiber; SDF: soluble dietary fiber; DS: digestible starch; RS: resistant starch. $\uparrow, \uparrow$, and $\downarrow$ indicate high, intermediate, and low levels of each macronutrient. 
RS) and D (high SDF) could be indicated for reduction of the risk of colon cancer and coronary disease, as well as for the prevention of diseases related to insulin resistance (GUILLON; CHAMP, 2002; LUPTON; TURNER, 2003).

\subsection{Categorizing bean cultivars according to their micronutrient content}

the great range observed in the ash content (70\%) of bean cultivars (Table 1) suggests that the content of some essential minerals may vary significantly among the studied cultivars. Since common beans are an important source of iron and other minerals these micronutrients were also determined in the common beans evaluated (Table 3). According to the literature common beans exhibit a great range in mineral content (mg.100 g $\mathrm{g}^{-1}$ dry weight basis) such as Fe (2-18), $\mathrm{Zn}$ (1-7), $\mathrm{Mn}$ (1-2), Cu (0.20-1.96), Ca (55-284), Mg (38-369), and $\mathrm{P}$ (295-570) (AUGUSTIN et al., 1981; BARAMPAMA; SIMARD, 1993; VAZQUEZ-BLANCO et al., 1997; SAMMAN et al., 1999; NUNEZ-GONZALEZ et al., 2002). In this study, Fe, Zn, Mn, $\mathrm{Cu}, \mathrm{Ca}$, and $\mathrm{P}$ contents were similar to those found in the literature (Table 3). However, Mg content was slightly lower than previously reported values.

Considering the nutritional importance of beans as mineral source, cultivars evaluated in the present study were also classified, based on their similarity for the content of some micronutrients in the course of two consecutive harvests (Table 3). Bean cultivars were divided into four different groups. No significant differences were observed in $\mathrm{P}$ content among the groups formed. Group A that was formed by cultivars Iapar 31, Iraí, and Macanudo had low levels of all minerals evaluated $(\mathrm{Fe}, \mathrm{Zn}, \mathrm{Mn}, \mathrm{Cu}, \mathrm{Mg}$ ) with the exception of $\mathrm{Ca}$ that was found at intermediate levels in this group. Group B (Carioca, Guapo Brilhante, Minuano) had low levels of $\mathrm{Zn}$ and $\mathrm{Mn}$, intermediate levels of $\mathrm{Fe}$, and high levels of $\mathrm{Cu}, \mathrm{Ca}$, and $\mathrm{Mg}$. Group $\mathrm{C}$ (Diamante Negro, TPS Bonito, Valente) had low levels of Ca, intermediate levels of $\mathrm{Mn}$ and $\mathrm{Mg}$, and high levels of $\mathrm{Fe}, \mathrm{Zn}$, and $\mathrm{Cu}$. Group D (FTS Magnífico, FTS Soberano, Guateian 6662, Pérola, Rio Tibagi, TPS Bionobre, TPS Nobre) had the highest content for all minerals evaluated.

Changes in the mineral profile of beans can be explained by a variety of factors, including genotypic variability in absorption of minerals from soil (NUNEZ-GONZALEZ et al., 2001), effect of fertilizers on metallic composition of plants (SADIQ;
HUSSAIN, 1994), and levels of soil salinity (CARBONELLBARRACHINA; BURLO; MATAIX, 1998). In this study, the soil used for seeding and the fertilization practices were kept the same for all cultivars. Hence, the differences of mineral profile among the cultivars could be attributed to genotypic variability.

As observed for macronutrients, these changes in mineral levels have an important role in human nutrition, because different cultivars could be used for specific nutritional purposes such as mineral deficiencies. Based on Table 3 we can select cultivars with the highest levels of Fe, Zn, (groups C and D), and $\mathrm{Ca}$ (groups $\mathrm{B}$ and $\mathrm{D}$ ) for the prevention of these ordinary mineral deficiencies. The data presented here can also be useful for selecting cultivars for the development of new ones, with a more appropriate nutritional profile for populations with specific mineral dietary deficiencies.

\subsection{Effect of storage conditions on cooked beans}

The effects of storage conditions on DS and RS contents of cooked beans were evaluated using cultivars that had either low or high RS levels before cooking (Figure 1). DS content of cooked beans significantly reduced after storage at $4^{\circ} \mathrm{C}$ both for low and high RS cultivars. However, storage at $-20^{\circ} \mathrm{C}$ only reduced DS content of low RS cultivars (Figure 1a). RS content of both low and high RS cultivars was significantly increased after storage of cooked beans at $4{ }^{\circ} \mathrm{C}$, but at $-20{ }^{\circ} \mathrm{C}$ only low RS cultivars had a significant increase in RS content (Figure 1b). It is noteworthy that the increase in RS content during storage was much more pronounced for low than for high RS cultivars, in such a way that the RS profile of cultivars was inverted after storage at $-20{ }^{\circ} \mathrm{C}$ (Figure $1 \mathrm{~b}$ ). These results suggest that beans that have low RS content before cooking are more prone to retrogradation after cooking. Hence, we can propose that the behavior of bean starch during storage may vary among different cultivars. This observation may help to explain previous controversial results on the effects of cooking and storage conditions on starch levels of common beans. Some authors found a decrease in digestible starch and increase in resistant starch after storage at $4{ }^{\circ} \mathrm{C}$ (VARGAS-TORRES et al., 2004), others found no changes (LANDA-HABANA et al., 2004), and others found an increase in digestible starch (OSORIO-DIAZ et al., 2003).

The effects of storage conditions on TDF, IDF, and SDF contents of cooked beans were also evaluated using cultivars

Table 3. Groups formed by bean cultivars considering the levels of micronutrients. ${ }^{\star}$

\begin{tabular}{|c|c|c|c|c|c|c|c|}
\hline \multirow[t]{2}{*}{ Group/cultivars } & \multicolumn{7}{|c|}{ Micronutrients (mg.100 g ${ }^{-1}$ dry weight) } \\
\hline & $\mathrm{Fe}$ & $\mathrm{Zn}$ & $\mathrm{Mn}$ & $\mathrm{Cu}$ & $\mathrm{Ca}$ & $\mathrm{Mg}$ & $\mathrm{P}$ \\
\hline A: Iapar 31; Irai; Macanudo & $\begin{array}{l}8.26^{\complement} \downarrow \\
(0.33)\end{array}$ & $\begin{array}{l}3.18^{\mathrm{b}} \downarrow \\
(0.08)\end{array}$ & $\begin{array}{l}1.35^{\mathrm{b}} \downarrow \\
(0.05)\end{array}$ & $\begin{array}{l}1.10^{\mathrm{b}} \downarrow \\
(0.12)\end{array}$ & $\begin{array}{l}257.23^{\mathrm{b} \uparrow} \\
(46.09)\end{array}$ & $\begin{array}{l}21.53^{\mathrm{b}} \downarrow \\
(1.17)\end{array}$ & $\begin{aligned} 358.59^{\mathrm{a}} \\
(11.12)\end{aligned}$ \\
\hline B: Carioca; Guapo Brilhante; Minuano & $\begin{array}{l}9.08^{\mathrm{b}} \uparrow \\
(0.15)\end{array}$ & $\begin{array}{l}3.20^{\mathrm{b}} \downarrow \\
(0.09)\end{array}$ & $\begin{array}{l}1.44^{\mathrm{b}} \downarrow \\
(0.02)\end{array}$ & $\begin{array}{l}1.39^{\mathrm{a}} \uparrow \\
(0.06)\end{array}$ & $\begin{array}{l}373.23^{\mathrm{a}} \uparrow \\
(22.15)\end{array}$ & $\begin{array}{l}23.88^{\mathrm{a}} \uparrow \\
(0.45)\end{array}$ & $\begin{array}{r}351.17^{\mathrm{a}} \\
(14.17)\end{array}$ \\
\hline C: Diamante Negro; TPS Bonito; Valente & $\begin{array}{l}9.26^{\mathrm{a}, \mathrm{b}} \uparrow \\
(0.11)\end{array}$ & $\begin{array}{l}3.57^{\mathrm{a}} \uparrow \\
(0.05)\end{array}$ & $\begin{array}{l}1.53^{\mathrm{a}, \mathrm{b}} \uparrow \\
(0.04)\end{array}$ & $\begin{array}{l}1.44^{\mathrm{a} \uparrow} \\
(0.03)\end{array}$ & $\begin{array}{l}147.01^{\mathrm{c}} \downarrow \\
(15.32)\end{array}$ & $\begin{array}{l}23.19^{\mathrm{a}, \mathrm{b}} \uparrow \\
(0.17)\end{array}$ & $\begin{array}{r}335.69^{\mathrm{a}} \\
(15.14)\end{array}$ \\
\hline $\begin{array}{l}\text { D: FTS Magnífico; FTS Soberano; Guateian 6662; } \\
\text { Pérola; Rio Tibagi; TPS Bionobre; TPS Nobre }\end{array}$ & $\begin{array}{l}9.65^{\mathrm{a}} \uparrow \\
(0.11)\end{array}$ & $\begin{array}{l}3.53^{\mathrm{a}} \uparrow \\
(0.09)\end{array}$ & $\begin{array}{l}1.67^{\mathrm{a}} \uparrow \\
(0.05)\end{array}$ & $\begin{array}{l}1.55^{\mathrm{a}} \uparrow \\
(0.05)\end{array}$ & $\begin{array}{l}399.75^{\mathrm{a}} \uparrow \\
(11.57)\end{array}$ & $\begin{array}{l}24.64^{\mathrm{a} \uparrow} \\
(0.38)\end{array}$ & $\begin{array}{r}342.47^{\mathrm{a}} \\
(9.61)\end{array}$ \\
\hline
\end{tabular}

${ }^{\star}$ Results are mean (standard error) of the group of cultivars indicated in the first column, each one analyzed in two harvests (2001/2002 and 2002/2003). Values within the same column that have no common superscript are significantly different $(\mathrm{P}<0.05$, Duncan's test). $\uparrow, \uparrow$, and $\downarrow$ indicate high, intermediate, and low levels of each micronutrient. 

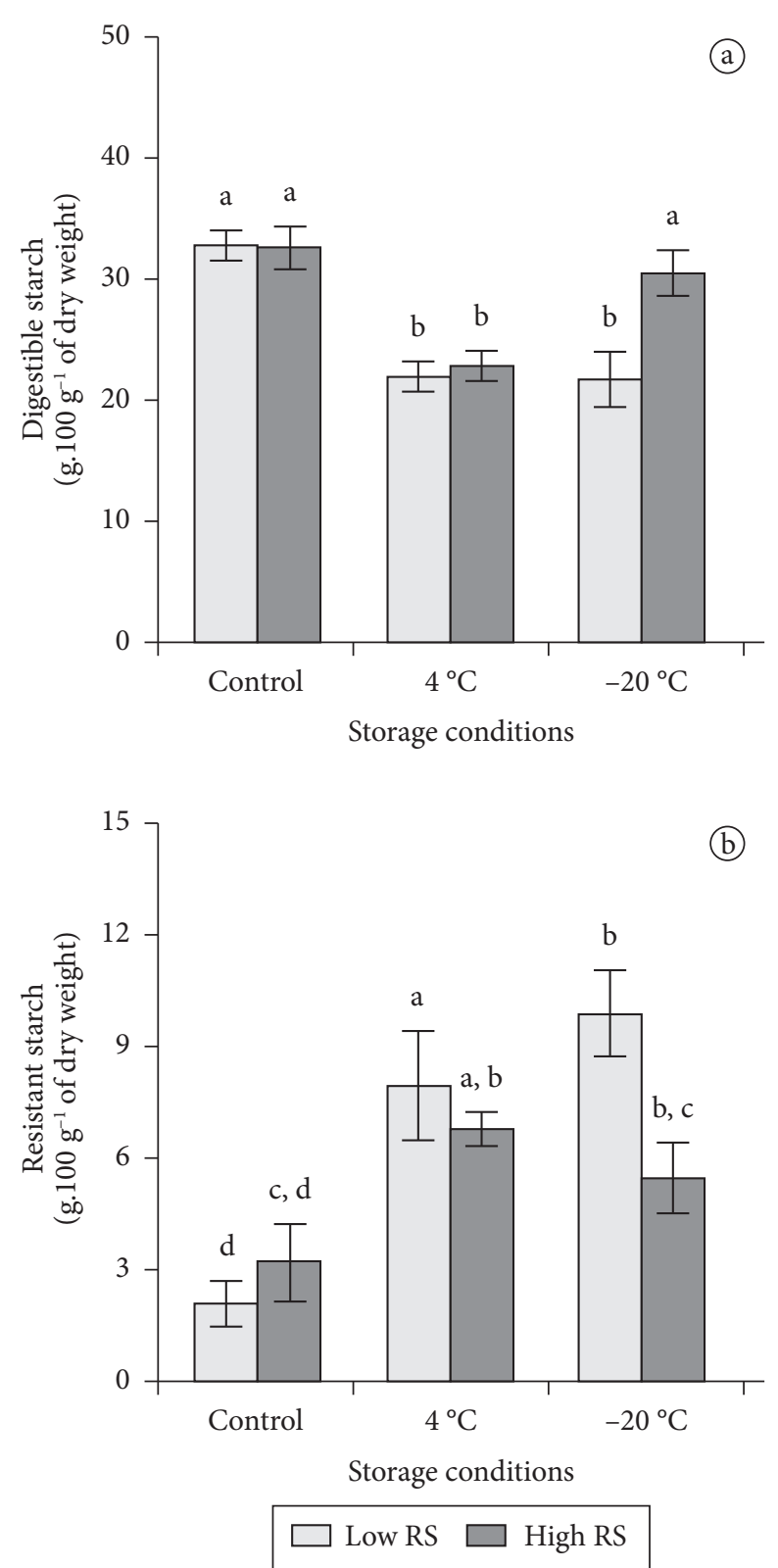

Figure 1. Effect of storage on digestible (a) and resistant (b) starch content of cooked common beans that had either a low or high resistant starch (RS) content before cooking. Results are mean \pm standard error $(\mathrm{n}=4)$. Bars within the same panel that have no common letters are significantly different $(\mathrm{P}<0.05)$.

that had either low or high RS levels before cooking (Figure 2). TDF (Figure 2a), IDF (Figure 2b), and SDF (Figure 2c) contents of cooked beans did not change during storage.

Previous studies on the dietary fiber of common beans focused on the effects of cooking and revealed variable results, since either increase or decrease of TDF, IDF, and SDF was observed by different authors (HUGHES; SWANSON, 1989; KUTOS et al., 2003). We did not find any study concerning the effects of different storage conditions on DF levels of common beans. In the present study we demonstrated that DF content did not change during storage of cooked beans. RS has been
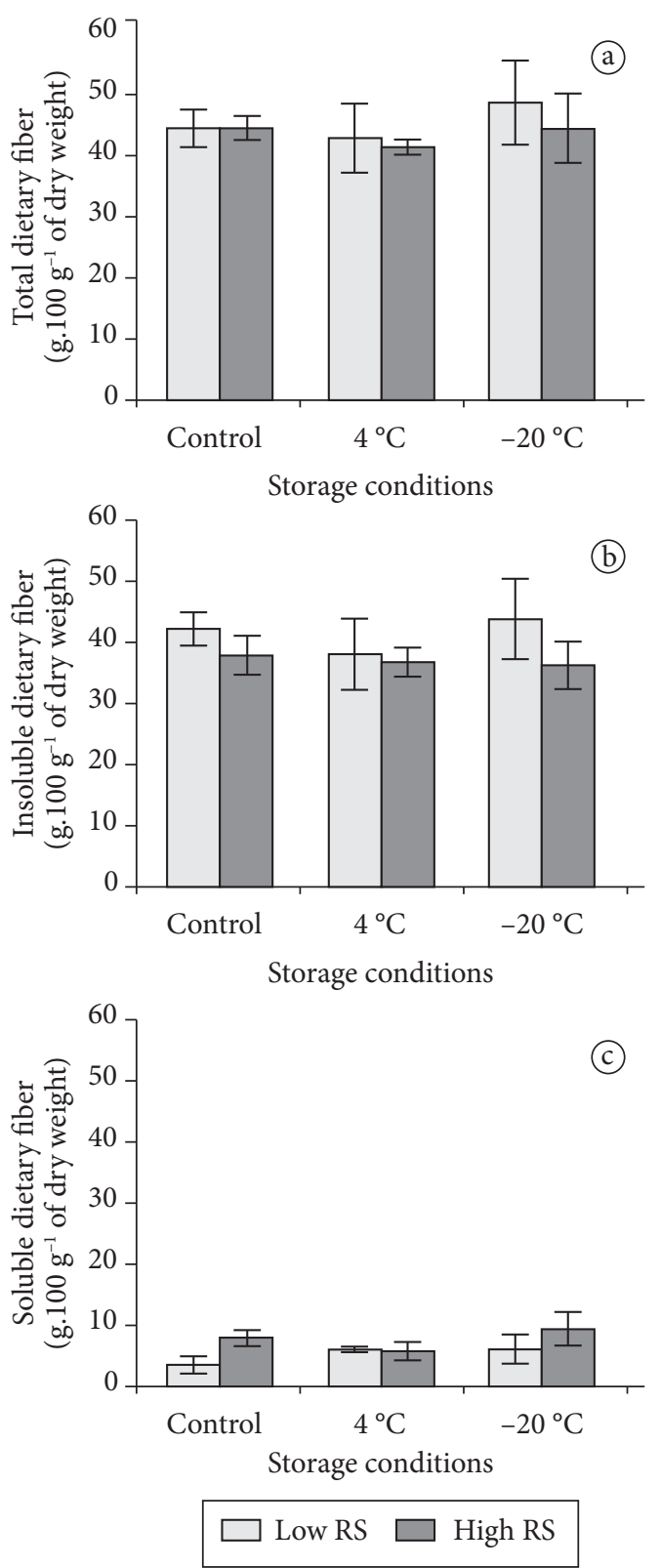

Figure 2. Effect of storage on total dietary fiber (a), insoluble fiber (b), and soluble fiber (c) of cooked common beans that had either a low or high resistant starch (RS) content before cooking. Results are mean \pm standard error $(n=4)$. Statistical analysis did not reveal any significant difference among samples on the evaluated parameters.

suggested to be a component of IDF in the assay procedure used in the present study (KUTOS et al., 2003), and it did change during storage (Figure 1). However, no change was observed in IDF fraction, probably because RS contributes to a small part of this fraction in cooked beans (10-20\%).

\section{Conclusions}

It was possible to identify groups of cultivars with different nutritional features. Guateian 6662 and Rio Tibagi appeared to be the most suitable cultivars to prevent nutritional deficiencies, 
because they had high PROT, DS, Fe, and Zn content. Cultivars with a composition more suitable for prevention of coronary disease and diseases related to insulin resistance (Iraí, Minuano, TPS Bonito, and specially Guateian 6662 and Rio Tibagi) were also identified. The observed variability among bean cultivars reveals the need to bring food composition tables up to date by including an expected range of nutrients for each cultivar.

In addition, it was shown that the increase in RS content and the decrease in DS during storage of cooked beans were higher for beans that had low RS content before cooking. These results may be useful in selecting cultivars for breeding and for specific uses in human nutrition.

\section{Acknowledgements}

The authors wish to thank Novozymes Latin American Ltda. for kindly donating the enzymes and Doles (GO, Brazil) for donation of the GOP test kit. T. Emanuelli is the recipient of a CNPq research fellowship. L.P. da Silva is the recipient of a CAPES/PRODOC fellowship.

\section{References}

ANTUNES, P. L. et al. Valor nutricional de feijão (Phaseolus vulgaris L.), cultivares Rico 23, Carioca, Piratã-1 e Rosinha-G2. Revista Brasileira de Agrociência, v. 1, n. 1, p. 12-18, 1995.

ASSOCIATION OF OFFICIAL ANALYTICAL CHEMISTS - AOAC. Official methods of analysis of the AOAC. 16 ed. Arlington, 1995.

AUGUSTIN, J. et al. Variation in the vitamin and mineral content of raw and cooked commercial Phaseolus vulgaris classes. Journal of Food Science, v. 46, n. 6, p. 1701-1706, 1981.

BANDINELLI, D. G. et al. Botanical composition of natural pasture as affected by phosphorus sources, lime and introduction of winter forage species. Ciência Rural, v. 35, n. 1, p. 84-91, 2005.

BARAMPAMA, Z.; SIMARD, R. E. Nutrient composition, protein quality and antinutritional factors of some varieties of dry beans (Phaseolus vulgaris) grown in Burundi. Food Chemistry, v. 47, n. 2, p. 159-167, 1993.

CARBONELL-BARRACHINA, A. A.; BURLO, F.; MATAIX, J. Response of bean micronutrient nutrition to arsenic and salinity. Journal of Plant Nutrition, v. 21, n. 6, p. 287-299, 1998.

CASTELLÓN, R. E. R. et al. Composição elementar e caracterização da fração lipídica de seis cultivares de caupi. Revista Brasileira de Engenharia Agrícola e Ambiental, v. 7, n. 1, p. 149-153, 2003.

GILBERT, G. A.; SPRAGG, S. P. Iodine sorption: "blue value". In: WHISTLER, R. L. (Ed.). Methods in carbohydrate chemistry. New York: Academic Press, 1964. p. 168-169. (v. 4)

GUILLON, F.; CHAMP, M. M. Carbohydrate fractions of legumes: uses in human nutrition and potential for health. British Journal of Nutrition, v. 88, suppl. 3, p. S293-S306, 2002.

HAIR Jr., J. F. et al. Multivariate data analysis. New Jersey: PrenticeHall, 1998.

HIGGINS, J. A. Resistant starch: metabolic effects and potential health benefits. Journal of AOAC International, v. 87, n. 3, p. 761-768, 2004.

HUGHES, J. S.; SWANSON, B. G. Soluble and insoluble dietary fiber in cooked common bean (Phaseolus vulgaris L.) seeds. Food Microstructure, v. 8, n. 1, p. 15-21, 1989.
KIGEL, J. Culinary and nutritional quality of Phaseolus vulgaris seeds as affected by environmental factors. Biotechnology, Agronomy, Society and Environment, v. 3, n. 4, p. 205-209, 1999.

KUTOS, T. et al. Dietary fiber content of dry and processed beans. Food Chemistry, v. 80, n. 3, p. 231-235, 2003.

LANDA-HABANA, L. et al. Effect of cooking procedures and storage on starch bioavailability in common beans (Phaseolus vulgaris L.). Plant Foods for Human Nutrition, v. 59, n. 4, p. 133-136, 2004.

LEMOS, L. B. et al. Características agronômicas e tecnológicas de genótipos de feijão do grupo comercial Carioca. Pesquisa Agropecuária Brasileira, v. 39, n. 4, p. 319-326, 2004.

LUPTON, J. R.; TURNER, N. D. Dietary fiber and coronary disease: does the evidence support an association? Current Atherosclerose Reports, v. 5, n. 6, p. 500-505, 2003.

NUNEZ-GONZALEZ, M. A. et al. Genotypic variability in absorption of minerals among bean (Phaseolus vulgaris L.) cultivars exposed to low nutrient stress. Crop Research, v. 22, n. 3, p. 408-423, 2001.

NUNEZ-GONZALEZ, M. A. et al. Variability in mineral profile in seven varieties of bean (Phaseolus vulgaris L.) adapted in North East of Mexico. Legume Research, v. 25, p. 284-287, 2002.

OSORIO-DIAZ, P. et al. Effect of processing and storage time on in vitro digestibility and resistant starch content of two bean (Phaseolus vulgaris L.) varieties. Journal of Science and Food Agricultural, v. 83 , n. 12 , p. $1283-1288,2003$.

SADIQ, M.; HUSSAIN, G. Effect of chelate fertilizers on dry matter and metallic composition of bean plants in a pot experiment. Journal of Plant Nutrition, v. 17, n. 9, p. 1477-1488, 1994.

SAMMAN, N. et al. Composition of different bean varieties (Phaseolus vulgaris) of northwestern Argentina (region NOA): cultivation zone influence. Journal of Agricultural and Food Chemistry, v. 47, n. 7, p. 2685-2689, 1999.

STATISTICAL PACKAGE OF SOCIAL SCIENCE - SPSS. SPSS for Windows Release 8.0. Chicago, 1997.

STORCK, C. R.; SILVA, L. P.; FAGUNDES, C. A. A. Categorizing rice cultivars based on differences in chemical composition. Journal of Food Composition and Analysis, v. 18, n. 4, p. 333-341, 2005.

THARANATHAN, R. N.; MAHADEVAMMA, S. Grain legumes: a boon to human nutrition. Trends in Food Science \& Technology, v. 14, n. 12, p. 507-518, 2003.

TEDESCO, M. J. et al. Análise de solo, plantas e outros materiais. 2 ed. Porto Alegre: UFRGS, 1995. (Boletim técnico n. 5)

THE MICHIGAN BEAN COMMISSION. Beans and inhibition of cancer. Saint Johns, 2008. Disponível em: <http://www. michiganbean.org/research.html>. Acesso em: 10 mar. 2008.

UNIVERSIDADE DE SÃO PAULO - USP. Tabela Brasileira de Composição de Alimentos. Versão 4.1. São Paulo, 2008. Disponível em: <http://www.fcf.usp.br/tabela>. Acesso em: 10 mar. 2008.

UNIVERSIDADE ESTADUAL DE CAMPINAS - UNICAMP. Tabela Brasileira de Composição de Alimentos: TACO. Versão 2. Campinas, 2008. Disponível em: <http://www.unicamp.br/nepa/ taco>. Acesso em: 10 mar. 2008.

VARGAS-TORRES, A. et al. Starch digestibility of five cooked black bean (Phaseolus vulgaris L.) varieties. Journal of Food Composition and Analysis, v. 17, n. 5, p. 605-612, 2004.

VAZQUEZ-BLANCO, M. E. et al. Determination of mineral elements in Galician green beans by atomic spectroscopy. Deutsche Lebensmittel-Rundschau, v. 93, n. 9, p. 286-287, 1997.

WALTER, M. Amido resistente: metodologias de quantificação e resposta biológica em ratos. Santa Maria, 2005. 96 p. Dissertação (Mestrado em Ciência e Tecnologia de Alimentos) - Universidade Federal de Santa Maria - UFSM. 